\title{
Greece: A critical assessment of Europeanization
}

\author{
Kostas Gemenis* $\quad$ Zoe Lefkofridi ${ }^{\dagger}$
}

Preprint of chapter published in The Europeanization of European Politics, edited by Mike Mannin and Charlotte Bretherton (New York: Palgrave Macmillan, 2013), pp. 95-107.

\section{Introduction}

The EU was never more prominent in Greece than during the economic crisis that began in 2008 and made the Greek polity, policies, and politics a topic of heated debate in the national parliaments and media of all other EU member states..$^{1}$ In early 2010, the Greek government successfully negotiated a mechanism that would provide rescue packages to ailing EU member-state economies to guarantee the financial stability of the Eurozone; and Greece became the first country to request the bilateral International Monetary Fund (IMF)-EU package (Gemenis 2010b, Tsarouhas 2012). The response of the Greek public seemed paradoxical, revealing a plurality that rejected the bailout agreement but which, at the same time, was in favor of remaining in the Eurozone (Tsebelis 2012). This seeming paradox can be understood by looking at the context in which attitudes toward European integration are formed in Greece - which can be understood as a struggle between pro-EU modernizers and adherents to what Diamandouros (1993) calls the "underdog culture" who, among other things, lament the loss of sovereignty to the EU.

Until the mid-1990s, it was customary to portray Greece as an awkward European partner. Greece after all, joined the European Communityi in

\footnotetext{
*Department of Public Administration, University of Twente, e-mail: k.gemenis@utwente.nl.

${ }^{\dagger}$ Institute for European Integration Research, University of Vienna, e-mail: zoe.lefkofridi@univie.ac.at.

${ }^{1}$ To avoid the confusion of multiple abbreviations, we will use the term EU throughout this chapter even when implying the impact of the EC in earlier periods.
} 
1981, as a newly consolidated democracy. The populist and Eurosceptic discourse of the socialist governments of the 1980s (Verney 1993), the nationalist position over the issue of the neighboring republic's name during the early 1990s, and Greece's support of Slobodan Milosevic during the Yugoslav wars soon after, did much to reinforce this image (Papadimitriou 1998). Arguably, the election of Costas Simitis as prime minister in 1996 heralded a new era for Greece (Tsoukalis 1999, Verney 1997). A politician who was never at ease with his party, the Panhellenic Socialist Movement (PASOK), Simitis was elected to implement a "modernization" program, which would bring the country closer to its European partners (Lyrintzis 2005). In fact, by the late 1990s, Europe was hardly a divisive issue in Greek politics, and this is when the boom in the literature on the "Europeanization of Greece" began. Public opinion had changed from an initial Eurosceptic stance into being overwhelmingly in favor of deeper European integration. In addition, although the salience of the EU has "oscillated between indifference and feverish debates" (Nezi, Sotiropoulos \& Toka 2010), with the exception of the Communist Party of Greece, the opposition lacked parties that mobilized against the EU (Dimitras 1992, Verney 2011). Perhaps, this Euro-euphoria reached its peak during the 2003 Greek presidency of the Council, which is widely considered as highly successful (Bunse 2004, Dimitrakopoulos \& Passas 2004). When these developments were viewed in contrast to other European countries, which were at the time experiencing the transition from a permissive consensus to a constraining dissensus in their European policy (Hooghe \& Marks 2008), Greece stood out positively (Deflem \& Pampel 1996). But was this increasingly positive stance vis-à-vis the EU accompanied by Europeanization understood as domestic change? This is the puzzle that the current crisis brought to the forefront.

The monitoring of the Greek economy by representatives of the IMF, the European Central Bank (ECB), and the European Commission brought to the surface many pathologies of the Greek administration which, in conjunction with the well-known structural constraints in Greek politics (Featherstone $2005 a$, Featherstone 2011), hamper the prospects of domestic change through Europeanization. Despite its 30-year EU membership, Greece proved to be a weak state rather than "a giant in the making" (Kalaitzidis 2009). In effect, these recent developments cast doubt on the claim that Greece had become Europeanized, or was at least in the process of becoming so. What went wrong? In this chapter, we seek answers to this question. Our narrative of Greece's Europeanization is twofold: We review existing works and contextualize this evidence in the current picture of Greece's relations with the EU. We contend that key to grasping Greece's Europeanization process is an understanding of the role played by major actors, namely Greek politi- 
cal elites and party organizations, especially those alternating in government that acted as managers of the state. In short, the Greek case provides us with a powerful reminder that party politics, a challenging (and neglected) area of Europeanization research, matters greatly.

The chapter is structured as follows: We begin by sketching out our conceptual and methodological considerations in section two and, in sections three to five, we critically review the literature regarding the EU's impact on national policies, institutions, and politics respectively. In section six, we draw on a synthesis of insights gained from this research to discuss current developments in Greece and its relationship with Europe.

\section{Conceptual and methodological considera- tions}

Europeanization is here understood as "an incremental process reorienting the direction and shape of politics to the degree that EC political and economic dynamics become part of the organizational logic of national politics and policy making" (Ladrech 1994, 71-72) or simply as "the process of reshaping national politics as a result of policies and preferences advanced through the EU level of governance" (Bache \& Jordan 2006, 30). Ioakimidis (2000, 74) distinguishes between "responsive" and "intended" Europeanization, where the former is an interactive process "between the national political system ... and the EU system," while the latter is understood as "modernization" in which domestic actors simply respond to challenges emanating from the top. Since Greece largely fits to the "intended" type of Europeanization Ioakimidis (2000), our approach is "top-down" in that it focuses "on the dimensions, mechanisms and outcomes by which European processes and institutions affect domestic-level processes and institutions" (Börzel \& Risse 2007, 485). More specifically, we view the emergence of policies and institutions at the EU level as the independent variable, the outcome of Europeanization as the dependent variable, and the degree of misfit, along with the preferences and positions of national actors and institutions, as intervening variables. Linking back to the conceptual discussion in chapter 1, our perspective is similar to that of Radaelli (2002, 127-130), who mapped domestic factors as intervening variables in explaining the process of Europeanization ${ }^{2}$ However, we acknowledge the possibility of interactions between the intervening variables, as well as the possibility of the outcome

\footnotetext{
${ }^{2}$ For the role of advocacy coalitions, veto players and legitimating policy discourse in Greece see Featherstone (2005a), Featherstone (2011), Ladi (2005) and Tsarouhas (2012).
} 
being dependent on factors unrelated to European integration.

Unfortunately, the methodological issues surrounding causality are rarely discussed explicitly in the Europeanization literature (Radaelli 2012). As Exadaktylos \& Radaelli (2009, 510) note, the most prominent theoretical frameworks lack exogenous variables affecting the outcome that could act as controls. Should we assume that these exogenous variables do not exist, or accept that some of the explanations might be spurious? If it is possible to attribute the cause of the outcome to a factor exogenous to European integration, could we argue that it is European integration that is causing the outcome? Establishing causality (Dunning 2008), improving case study analysis (Haverland 2006, Gerring \& McDermott 2007), the significance of process tracing (Gerring 2007, 172-185), or counterfactual reasoning (Gerring \& McDermott 2007, 172-185) are analytical problems to be borne in mind and are further considered in chapter 15.

Here, the following three sections review most of the published literature on the Europeanization of Greece. When possible, we separate studies focusing on different policies from studies focusing on institutions and politics, outline their conclusions regarding the outcome of Europeanization, and address the ways in which researchers use theoretical frameworks, empirical evidence, and methods to infer the impact of Europeanization ${ }^{3}$

\section{Policy}

We begin with the impact of European integration on national policiesby far the most analyzed dimension of Europeanization in Greece and elsewhere (Featherstone 2003).

Starting with citizenship and minorities policy, Pollis (1992) looks at the way Greece adheres to and respects European norms and values. She sees EU membership as exerting pressure on Greece "to abandon its claimed distinctiveness" (Pollis 1992, 176) and adopts a research design that compares policies surrounding freedom of religion in Greece, Portugal, and Spain. She shows that some policies in Greece are restricting religious freedom and speculates EU membership might facilitate the transformation of these policies. Similarly, Anagnostou (2005) sees policy misfit in the case of a policy that stipulated that individuals who are not ethnically Greek (for example Jews, Muslim Albanians, or Slavic speakers) and who left the country without the intention of returning (communists during the Civil War) could be deprived of citizenship. Using interviews with political leaders, experts, and officials,

\footnotetext{
${ }^{3}$ Note, however, that in some cases the conceptual foundations or the methodology followed is not made explicit.
} 
Anagnostou (2005, 347-350) concluded that the revocation of this policy was the result of rising awareness among political elites and experts that respecting human rights "enhanced the country's standing abroad." Fisher Onar \& Özgüneş (2010) also investigate the Europeanization of minority policy by comparing Greece to Turkey. They found that, despite the fact that the application of "carrots and sticks" for Turkey was associated with conditionality to enter the EU, Greece experienced a greater transformation of its minorities policy - an outcome best explained by the degree of national elite willingness to reform.

With regards to immigration, Mavrodi (2007) argued that EU membership has had a liberalizing effect on Greek policy. She argued that EU membership facilitates the spillover of immigration policies from old immigration countries (such as France and the UK) to new immigration countries such as Greece. By studying parliamentary debates about the adoption of immigration bills between 1991 and 2005, she found a significant EU impact both in terms of formal obligations under the Schengen system and voluntary adjustment. She then addressed the counterfactual question, "what if" Greece was not an EU member, discussing the impact of public opinion and domestic institutional factors (NGOs, trade unions). By using material such as Eurobarometer opinion polls and interviews, she was able to illustrate that the particular changes in immigration laws cannot be attributed to domestic factors (Mavrodi 2007, 167-170).

Turning to environmental policy, Kazakos (1999) sought to explain the impact of the EU by considering different mechanisms such as international agreements, EU legislation, financing by the Community support frameworks, and "learning" via exposure to policy networks. Although environmental policy is one of the hard policy areas in the EU, he concluded that the outcome of Europeanization is largely determined by actors at the national level. Thus, he argued that EU "legislation is often not implemented due to the absence of effective controls, the lack of political will and administrative inadequacy, in a climate not favoring environmental protection" (Kazakos 1999, 384). Europeanization of environmental policy was also explored by Ladi (2007) who adopted an analytical framework based on policy misfit, as outlined in chapter 1. Using participant observation and focus groups with members of the Ministry for Environment, Physical Planning and Public Works, the European Commission and environmental nongovernmental organizations (NGOs), she found that the outcome of Europeanization is a matter of interpretation. Assuming that environmental policy has not been a priority for the Greek government, the counterfactual argument goes that any convergence to EU standards should be attributed to the impact of the EU and any divergence to the penetration of interests at the 
national level.

With regards to social policy, Sotiropoulos (2004) investigated the impact of the EU by differentiating between changes in policies and changes in policy-making. To do so, he contrasted factors emanating from the EU with domestic explanations such as the nature of political culture, organizational deficiencies in public administration, and the interests of different social groups. By using a longitudinal design based on welfare state indicators, he finds little substantive change in policy outcomes. Whatever changes were observed concerned policymaking and were concentrated in specific areas such as employment, vocational training, childcare, and pensions. Sotiropoulos' emphasis on institutional legacies hindering reform is affirmed by Featherstone's (2005b) study of the pension system, which assesses reform as "slow" and "modest" despite both national stimuli and EU pressures related to the fiscal constraints on government budgets set up by EMU. Due to the powerful domestic constraints, this author questions Greece's ability to remain in the EU's core (Featherstone 2005b, 747-748). A further, empirical study examining Greek response to evolving EU social policy over time complements this picture: "The state-centered society and the bad public administration constrain the economic and social modernization processes, toughen problem solving, restrict initiatives, and negatively affect policy effectiveness overall" (Sakellaropoulos 2007, 220). It is worth noting, here, that comparative research on compliance with EU social policy directives classifies Greece (together with France and Portugal) in the "world of neglect": This is a category of countries where bureaucratic inertia and apolitical transposition processes are related to a poor compliance culture in both political and administrative systems (Falkner, Treib \& Hartlapp 2005, 317-341). This has often led the Commission to bring Greece to the European Court of Justice (ECJ) and involves enormous waste of resources in paying ECJ-imposed fines for failure to comply with policy directives that Greek governments themselves agreed upon at the EU level (Falkner 2011).

Finally, a highly researched policy area with regards to Europeanization in Greece is foreign policy. This is surprising given that it is widely considered as the last bastion of national sovereignty (Ladrech 2010, 190-191). Economides (2005), who researched the impact of CFSP on Greek foreign policy, argues that Greece's membership in the EU diffused specific values, norms, and practices in policy-making at the national level. The author claims that the style of Greek foreign policy has become more Europeanized and that, at the same time, Greece was able to upload its "foreign policy preferences and interests in at least two key issue areas, Turkey and Cyprus, onto the EU agenda" (Economides 2005, 472-473). Similarly, based on a review of the literature and interviews with researchers Tsardanidis \& Stavridis (2005, 224) 
conclude that "all agree that there has been a successful Europeanization of Greek foreign policy." Yet, such an enthusiastic conclusion might simply reflect experts' wishful thinking. This might, in turn, emanate from their close relationship with actual policy developmentsand perhaps, also, political parties (Ladi 2005).

\section{Institutions}

With regards to the Europeanization of institutions in Greece, Spanou (1998) studies the EU impact on administrative systems. Focusing especially on how the Greek state institutions deal with the implementation of EU policies, she argues that various extra-institutional, informal processes related to the interaction between state-society and politics-administration moderate the responses of the Greek system to EU challenges. Also, she argues that the gap between formal rules and informal practices may favor or inhibit responsiveness. These findings complement the research on the Europeanization of policy mentioned above.

Most research in this field has focused on the impact of the EU on the institutions relating to the territorial organization of the country. Paraskevopoulos $(1998,39)$ researched the case of EU regional policy as an adaptational pressure "for the structure of the state and the system of public administration." Using network analysis based on interviews with prominent regional actors, he sought to explain the differences in institutional building and adaptation. The findings suggest that, although European integration provided a "positive external shock," the outcomes reflected interaction between EUlevel variables and preexisting differences in the institutional capacities of the Greek regions. Similarly, Getimis \& Grigoriadou (2004, 6-7) see EU membership as a political and economic opportunity structure that interacts with the different political structures of member states. In a comparative study of municipalities in the wider Athens metropolitan area, they use semistructured interviews to investigate "the influence of EU policies and their funding requirements on partnership formation and on the emergence of patterns of civic participation in the process of urban policy-making" (Getimis \& Grigoriadou 2004, 14). Their findings suggest an EU impact on partnership formation and community involvement in specific projects, but the outcomes are largely defined by factors relating to party politics, sectoral interests, and clientelistic networks.

That said, Giannakourou (2005) finds European Spatial Development Perspective (ESDP) and other EU-led planning instruments to have generated important changes in domestic patterns of spatial planning systems. 
These changes, she argues, are not the product of forced compliance to EU models but occur through complex socialization and learning processes that expose domestic actors to new ideas, practices, and methods and induce cultural innovation. This assessment is made based on a comparison of the EU planning policies impact on five Mediterranean states (France, Greece Italy, Portugal, and Spain).

One of the most important EU policies for Greece, and other countries of the periphery such as Ireland and Portugal, has been the cohesion policy, through which the Commission targeted the territorial organization of member states, seeking to strengthen the regions vis-à-vis the central governments. Andreou (2006) uses a historical institutionalist lens to examine the implementation of this policy in Greece. He suggests that "EU influence did not manifest itself principally in the field of territorial relations, but in the domain of policy objectives, policy style and practices" (Andreou 2006, 253). In particular, he found that adaptational pressures are usually accommodated in ways that do not challenge centrally controlled (by the executive) structures. For example, the creation of NUTS (Nomenclature of Territorial Units for Statistics) regions to absorb EU funds "did not involve institutional reform, but the patching of new policies and institutions onto existing oneswithout changing the latter" (Andreou 2006, 253).

Finally, we turn to two prominent institutions: the government and parliament. Featherstone (1998) argues that, where discretion is available to the Greek government, policy-making tends to advantage small circles of actors within the core executive. Hence, one of the impacts of EU membership is that the already centralized Greek executive was furthered strengthened in relation to other domestic actors such as the parliament. Dimitrakopoulos (2001) assessed the parliament's response to the challenges of EU membership by focusing on its formal structure and goals. The author adopted a comparative framework, where the Greek parliament was compared to those in France and the UK, but was unable to draw a clear, causal Europeanization effect. Although it was argued that developments in national parliaments followed "developments at the level of the EU, thus underlining the reactive approach" (Dimitrakopoulos 2001, 406), the absence of controls at the national level suggest that the observed relationship might be spurious. Similarly, Zervakis \& Yannis (2001) chart post-accession changes in the Greek parliament. Although they do not use a Europeanization framework, they argue that the most visible impact of European integration was the establishment of the committee for European affairs in June 1990, due to a motion by the European Parliament stressing the need for such committees in all member states. 


\section{Politics}

As pointed out by Featherstone (2003), Hix \& Goetz (2000) and others, the impact of European integration on the politics dimension is the least studied area in Europeanization research. In the Greek case, although political parties are mentioned in analyses of policy reform, and of Europeanization of policy, as powerful actors in the process, there are very few studies that analyze political parties in this context. Starting with national party systems, Mair (2000) famously argued that the EUs impact in terms of party system format and mechanics is practically nonexistent. Lyrintzis, in his 2005 review of the cultural and political context within which Greek parties operate, did not explicitly discuss the impact of European integration. As Greece did not experience the creation of new parties that mobilized solely on the issue of EU membership, we could concur with Mair (2000) on the absence of Europeanization effects in the Greek party system. The May and June 2012 elections, however, offer some evidence to the contrary. In the two-year period prior to the signing of the bailout agreement, the two parties alternating in government-PASOK and New Democracy (ND) - experienced fissures because of the austerity measures and loss of sovereignty associated with the agreement. Consequently, the Greek party system witnessed the highest number of parliamentary parties since 1974 . The most visible of the new parties that mobilized against the bailout agreement is "Independent Greeks" (led by a former ND deputy) which gained about 10 percent of the vote in the May election. The Independent Greeks do not mobilize against the EU as such, but against the policy measures associated with membership. Given this, as well as the recent volatility of the Greek electorate, we cannot conclude yet that the EU has had a significant impact on the Greek party system.

Turning to individual political parties, Ladrech (2002, 396-400) identified four possible areas of potential EU impact: policy content, party organization, patterns of party competition, party-government relations, and relations beyond the national party system. To provide for a theoretical mechanism that would explain the differential impact of the EU on parties, Lefkofridi (2009b, 2009a) links the party Europeanization literature with classic theories of party change and behavior. Seeking to explain national parties' (lack of) change in a constantly changing EU environment, she focuses on how the EU impacts party goals (votes, office, and policy). More specifically, she argues that the extent to which the EU environment may trigger party change, and the kind of the change induced, are conditioned by party-related variables, namely their goals, and by intraparty constellations of power and organizational structures. 
Her empirical exploration (Lefkofridi 2009b), based on qualitative analysis of party manifestos, semistructured interviews, and archival sources, examines the role of Europe in party discourse, as well as in policy and organizational change. An important insight gained by this research is that, while parties do not change positions on the EU and its policies over time, they change the way they refer to the EU by using it instrumentally in their discourse, insofar as it fits their vote-maximization strategy (Lefkofridi 2010). She traces the EU impact on Greek parties' structural evolution, changes of the selection procedures for important party posts (leadership, MPs, and MEPs), the creation of committees, and so forth through time (Lefkofridi $2009 b$, Lefkofridi 2010). The results suggest that, with the exception of the coalition of the Left and Progress (SYN), Greek political parties have not realized the need to adapt their organization for the purpose of pursuing policy in a multilevel context. The two major parties opted for using the state's structure or hiring external experts. However, in the context of a major restructuring induced by electoral defeat, PASOK made some EU-related changes (for example upgrade of MEPs and new rules for coordination between MPs and MEPs).

The impact on policy and programmatic content was partially addressed by Gemenis (2010b), who used PASOK as an illustrative case in his crossnational comparison. Focusing on environmental policy positions and following a process-tracing approach using official party documents, he concluded that there was little in the environmental discourse of the party that can be attributed to the impact of the EU. The only evidence supporting the Europeanization hypothesis was PASOK's adoption of the "sustainable development" concept between 1993 and 2000 (Gemenis 2010a, 187-189).

With regard to party competition, Greek political parties were studied in the context of a comparative analysis of six EU member states by Lefkofridi \& Kritzinger (2008), who explored the context of European political competition and on which grounds national parties compete in EP elections. They assessed party awareness of the EU context by looking at how present/absent this was in the electoral debate by distinguishing between policy areas where the EU has competence and those policies for which it does not. The analysis is based on data collected by the Euromanifestos Project (1999-2004). Their findings suggest that awareness can be observed to varying degrees amongst political parties: Greek parties, like most parties examined, have become increasingly aware of the European context in which they operate, but in terms of action induced (for instance concerning the way they structure their competition in the political space) the impact of the $\mathrm{EU}$ is minimal. 


\section{Discussion and Conclusion}

Looking at Greek policy, institutions, and politics, we could say that the evidence for EU impact looks thin. Apart from speculative assessments (Pollis 1992), and the overly positive assessment on the Europeanization of foreign policy, most researchers stress the importance of variables at the national level which may be independent of EU pressures (Anagnostou 2005, Gemenis $2010 a$, Fisher Onar \& Özgüneş 2010, Sotiropoulos 2004). This is also evident in the area of political parties, where we observe great resilience despite a changing EU environment (Gemenis 2010a, Lefkofridi 2009b, Lefkofridi \& Kritzinger 2008). Moreover, as adaptational pressures also emanate from agreements at the international level, it is difficult to distinguish the effect of Europeanization from that of globalization (Ladi 2007). For many authors, it was "not easy to assess which factor is more or less important in determining public policy in Greece" (Kazakos 1999, 377). This not surprising considering that, in many studies, the bulk of empirical evidence was inadequate to give the necessary leverage for causal inference.

When methodological considerations of establishing causality are taken into account, it seems that, apart from policy harmonization in areas related to the internal market, the strongest evidence for change in Greece emanating from the EU concerns immigration policies, where the EU was shown to have had a liberalizing effect (Mavrodi 2007). Mavrodi's contrasting findings in assessing two different potential sources of Europeanization (Mavrodi 2007, Mavrodi 2008) and Ladrech's (2010, 30-31) note that researchers should consider the important distinction between "hard" and "soft" EU policies when investigating the EU impact reminds us that the degree of adaptational pressures is an important factor in determining Europeanization outcomes. Hard policies require member states to implement the relevant EU legislation, whereas soft policies are those which merely create opportunity structures for change at the national level. Whether domestic actors will seize them depends on the domestic institutional and political context. Illuminating in this regard are Ladi's (2005) observations on the role played by experts in Greek policy reform and Nezi, Sotiropoulos, and Toka's (2010) findings about the identity of national parliamentarians and their attitude to the EU in comparison to the Greek public. Ladi (2005, 293-294) extends the policy advocacy coalition framework by emphasizing political, economic, and social interests and the way they form belief systems and shows that the links between such coalitions and political parties are crucial for the successful outcome of the experts' efforts toward modernization. In the study by Nezi, Sotiropoulos \& Toka (2010), the public proved to be more ethnocentric than MPs with regard to the appropriate level where policy should be formulated 
whereas MPs were positive toward delegation of policy competences to the EU level. However, these scholars also found that political elites did not think about Europe on its own terms but that their views Europe depended on political ideology and party affiliation.

The critical assessment of the literature in this chapter echoes Haverland (2007, 65-66) in that research strategies matter for our understanding of Europeanization. Our review shows that, despite 30-year long membership in supranational institutions, the Greek polity, policy, and politics have seen little change that could be unambiguously attributed to the EU. How does this picture connect to the current political and economic events in Greece and Europe?

Due to lack of Europeanization, or put more mildly, due to a superficial Europeanization at the policy, institutional, and party level, Greece could not live up to the expectations of the single market and especially EMU. This is not to say that non-Europeanization "caused" the sovereign debt crisis. But if Greece had been Europeanized: (a) it would not be so illprepared for dealing with the crisis (b) it would be more credible and EU partners would not be as reluctant to support Greece as they were at the beginning of the crisis. Here it is worth mentioning that much depends upon the political elites' will to push change forward (Tsarouhas 2012). Despite the fact that the country was on the brink of economic collapse, political parties failed to reach consensus and form coalition governments prepared to pursue necessary policy change. On the contrary, they kept on acting based on self-interest and vote-optimizing tactics. But as Greece was found in a state of Greece's complete dependency on EU partners' credible commitments, its own credibility as a reliable partner was increasingly shaken. The crisis forces debate about the pros and cons of European integration for Greece and the duties that accompany the rights of EU membership that Greek political elites are unable to conductperhaps because they were the ones that most forcefully resisted change.

Consequently, to turn this empirical conclusion to a normative one, we could say that the impact of Europeanization in Greece has been limited. To the (Euro)skeptics, who tend to attribute to the EU many of the ills facing the country today, we offer the evidence summarized in this chapterthat it was mostly domestic factors shaping the policy, institutions, and politics in Greece. We therefore suggest consideration of the counterfactual situation: What would Greece look like if there had been a significant impact of the EU and the Greek polity and politics had not been marred by administrative deficiencies and clientelistic/particularistic (as opposed to public policyoriented) parties? The domestically and internationally discredited Greek political elites, who for decades mismanaged the state, as well as Greek and 
EU resources, are now called to save the country from a severe economic but also deeply political and social crisis to which their behavior contributed. We contend that to "Europeanize" Greece, Greek elites need to change the way they think about Europe, and to adapt their organizations so as to pursue policy in a multilevel, transnational environment.

\section{References}

Anagnostou, Dia. 2005. "Deepening democracy or defending the nation? The Europeanization of minority rights and Greek citizenship." West European Politics 28:335-357.

Andreou, George. 2006. "EU cohesion policy in Greece: patterns of governance and Europeanization." South European Society 86 Politics 11:241259.

Bache, Ian \& Andrew Jordan. 2006. Europeanization and domestic change. In The Europeanization of British politics, ed. Ian Bache \& Andrew Jordan. Basingstoke: Palgrave Macmillan, pp. 17-33.

Börzel, Tanja A. \& Thomas Risse. 2007. Europeanization: the domestic impact of European Union politics. In Handbook of European Union Politics, ed. Knud Erik Jørgensen, Mark Pollack \& Ben J. Rosamond. London: Sage, pp. 483-504.

Bunse, Simone. 2004. "The 2003 Greek Council presidency." Mediterranean Politics 9:248-257.

Deflem, Mathieu \& Fred C. Pampel. 1996. "The myth of postnational identity: popular support for European unification." Social Forces 75:119143.

Diamandouros, P. Nikoforos. 1993. Politics and culture in Greece, 1974-91: an interpretation. In Greece 1981-89: the populist decade, ed. Richard Clogg. London: St. Martin's Press pp. 1-25.

Dimitrakopoulos, Dionyssis G. 2001. "Incrementalism and path dependence: European integration and institutional change in national parliaments." Journal of Common Market Studies 39:405-422.

Dimitrakopoulos, Dionyssis G. \& Argyris G. Passas. 2004. "The Greek presidency: in the shadow of war." Journal of Common Market Studies 42(supplement):43-46. 
Dimitras, Panayote Elias. 1992. "The pro-EEC conversion of Greek public opinion (1981-90)." International Journal of Public Opinion Research $4: 37-50$.

Dunning, Thad. 2008. "Review of Case study research: principles and practices by John Gerring." Journal of Politics 70:282-283.

Economides, Spyros. 2005. "The Europeanization of foreign policy in Greece." West European Politics 28:471-491.

Exadaktylos, Theofanis \& Claudio M. Radaelli. 2009. "Research design in European studies: the case of Europeanization." Journal of Common Market Studies 47:507-530.

Falkner, Gerda. 2011. "Fines and Second ECJ Judgments as modes of EU governance." Paper presented at the ECPR General Conference, Reykjavik, August 2527.

Falkner, Gerda, Oliver Treib \& Miriam Hartlapp. 2005. Complying with Europe: EU harmonisation and soft law in the member states. Cambridge: Cambridge University Press.

Featherstone, Kevin. 1998. "Europeanization and the centre periphery: the case of Greece in the 1990s." South European Politics \& Society 3:23-39.

Featherstone, Kevin. 2003. Introduction: in the name of 'Europe'. In The politics of Europeanization, ed. Kevin Featherstone \& Claudio M. Radaelli. Oxford: Oxford University Press, pp. 3-26.

Featherstone, Kevin. 2005a. "Introduction: 'Modernisation' and the structural constraints of Greek politics." West European Politics 28:223-241.

Featherstone, Kevin. 2005b. "'Soft' coordination meets 'hard' politics: the European Union and pension reform in Greece." Journal of European Public Policy 12:733-750.

Featherstone, Kevin. 2011. "The Greek sovereign debt crisis and EMU: a failed state in a skewed regime." Journal of Common Market Studies 49:193-217.

Fisher Onar, Nora \& Meriç Özgüneş. 2010. "How deep a transformation? Europeanization of Greek and Turkish minority policies." International Journal on Minority and Group Rights 17:111-136. 
Gemenis, Kostas. 2010a. The impact of the European Union on political parties' environmental policy positions. PhD thesis Keele University.

Gemenis, Kostas. 2010b. "Winning votes and weathering storms: The 2009 European and parliamentary elections in Greece." Representation 46:353-362.

Gerring, John. 2007. Case study research: principles and practices. Cambridge: Cambridge University Press.

Gerring, John \& Rose McDermott. 2007. "An experimental template for case study research." American Journal of Political Science 51:688-701.

Getimis, Panagiotis \& Despoina Grigoriadou. 2004. "The Europeanization of urban governance in Greece: a dynamic and contradictory process." International Planning Studies 9:5-25.

Giannakourou, Georgia. 2005. "Transforming spatial planning policy in Mediterranean countries: Europeanization and domestic change." European Planning Studies 13:319-331.

Haverland, Marcus. 2006. "Does the EU cause domestic developments? Improving case selection in Europeanisation research." West European Politics 29:134-146.

Haverland, Marcus. 2007. Methodology. In Europeanization: new research agendas, ed. Paolo Graziano \& Maarten Peter Vink. Basingstoke: Palgrave Macmillan, pp. 59-70.

Hix, Simon \& Klaus Goetz. 2000. "Introduction: European integration and national political systems." West European Politics 23(1):1-16.

Hooghe, Liesbet \& Gary Marks. 2008. "A postfunctionalist theory of European integration: From permissive consensus to constraining dissensus." British Journal of Political Science 39:1-23.

Ioakimidis, P.C. 2000. "The Europeanization of Greece: an overall assessment." South European Politics 86 Society 5:73-94.

Kalaitzidis, Akis. 2009. Europe's Greece: a giant in the making. Basingstoke: Palgrave Macmillan.

Kazakos, Panos. 1999. "The 'Europeanization' of public policy: the impact of European integration on Greek environmental policy." Journal of European Integration 21:369-391. 
Ladi, Stella. 2005. "The role of experts in the reform process in Greece." West European Politics 28(2):279-296.

Ladi, Stella. 2007. "Exeurōpaismos kai allages dēmosiōn politikōn: hē periptōsē tēs hellēnikēs perivallontikēs politikēs [Europeanization and public policy change: the case of Greek environmental policy]." Greek Political Science Review issue 29:40-60.

Ladrech, Robert. 1994. "Europeanization of domestic politics and institutions: the case of France." Journal of Common Market Studies 32:69-88.

Ladrech, Robert. 2002. "Europeanization and political parties: Towards a framework for analysis." Party Politics 8:389-403.

Ladrech, Robert. 2010. Europeanization and national politics. Basingstoke: Palgrave Macmillan.

Lefkofridi, Zoe. 2009a. Ho exeurōpaismos tō ethnikōn kommatōn [The Europeanization of national parties]. In Kommata kai politikē stēn Hellada [Parties and politics in Greece], ed. Iannis Konstantinidis, Nikos arantzidis \& Takis S. Pappas. Athens: Kritiki pp. 75-100.

Lefkofridi, Zoe. 2009b. National party response to European integration: a theoretical framework \& evidence from the case of Greece (1974-2007) $\mathrm{PhD}$ thesis University of Vienna.

Lefkofridi, Zoe. 2010. "Changing policy, not structure: Greek office-seekers facing voters and EU partners." Paper presented at 2010 ECPR Joint Sessions of Workshops, Mnster, March 2223.

Lefkofridi, Zoe \& Sylvia Kritzinger. 2008. "Battles fought in the EP arena: Developments in national parties Euro-manifestos." Austrian Journal of Political Science 37:273-296.

Lyrintzis, Christos. 2005. "The changing party system: Stable democracy, contested 'modernisation'." West European Politics 28:242-259.

Mair, Peter. 2000. "The limited impact of Europe on national party systems." West European Politics 23(4):27-51.

Mavrodi, Georgia. 2007. Ulysses turning European: the different faces of 'Europeanization' of Greek immigration policy. In Europeanization of national policies and politics of immigration: between autonomy and the European Union, ed. Thomas Faist \& Andreas Ette. London: Palgrave pp. 157-178. 
Mavrodi, Georgia. 2008. "The Impact of the ECHR and the European Court of Human Rights on the rights of third country nationals in Greece." Journal of Immigration Asylum and Nationality Law 22:45-62.

Nezi, Roula, Dimitri A. Sotiropoulos \& Panayiota Toka. 2010. "Attitudes of Greek parliamentarians towards European and national identity, representation and scope of governance." South European Society \& Politics 15:79-96.

Papadimitriou, Despina. 1998. "The image of Greece in the European and the international press, 1992-1994." Études Helléniques-Hellenic Studies 1:91-98.

Paraskevopoulos, Christos J. 1998. "Social capital, institutional learning and European regional policy: evidence from Greece." Regional \&6 Federal Studies 8:31-64.

Pollis, Adamantia. 1992. "Greek national identity: religious minorities, rights and European norms." Journal of Modern Greek Studies 10:171-195.

Radaelli, Claudio M. 2002. "The domestic impact of european union public policy: notes on concepts, methods, and the challenge of empirical research." Politique européenne 5:105-136.

Radaelli, Claudio M. 2012. Europeanization: the challenge to establish causality. In Research design in European studies: establishing causality in Europeanization, ed. Theofanis Exadaktylos \& Claudio M. Radaelli. Basingstoke: Palgrave Macmillan pp. 1-17.

Sakellaropoulos, Theodoros. 2007. Greece: the quest for national welfare expansion through more social Europe. In The Europeanization of social protection, ed. Jon Kvist \& Juho Saari. Bristol: Policy Press pp. 211227.

Sotiropoulos, Dimitri A. 2004. "The EU's impact on the Greek welfare state: Europeanization on paper?" Journal of European Social Policy 14:267282.

Spanou, Calliope. 1998. "European integration in administrative terms: a framework for analysis and the Greek case." Journal of European Public Policy 5:467-484.

Tsardanidis, Charalambos \& Stelios Stavridis. 2005. "The Europeanisation of Greek foreign policy: a critical appraisal." Journal of European Integration 27:217-239. 
Tsarouhas, Dimitris. 2012. "The political origins of the Greek crisis: Domestic failures and the EU factor." Insight Turkey 14(2):83-98.

Tsebelis, George. 2012. "Den yparchei Hellēnikos 'laos', mono Hellēnes psēphoforoi [There is no Greek 'people', only Greek voters]." Protagon, May 28. http://www.protagon.gr/?i=protagon.el.article\&id=15580.

Tsoukalis, Loukas. 1999. "Greece: like any other European country?" The National Interest Spring.

Verney, Susannah. 1993. From the 'special relationship' to Europeanism: PASOK and the European Community, 1981-89. In Greece 1981-89: the populist decade, ed. Richard Clogg. London: Macmillan, pp. 131153.

Verney, Susannah. 1997. "Greece: a new era." Mediterranean Politics 2:193200.

Verney, Susannah. 2011. "Euroscepticism in southern Europe: A diachronic perspective." South European Society \& Politics 16:1-29.

Zervakis, Peter \& Nikos Yannis. 2001. The parliament of Greece: slow but constant moves towards European integration? In National parliaments on their way to Europe: losers or latecomers?, ed. Andreas Maurer \& Wolfgang Wessels. Baden-Baden: Nomos pp. 147-172. 